Janko Trupej

Neodvisni raziskovalec

Laška vas 21, 3273 Jurklošter

Slovenija

janko.trupej@gmail.com
UDK 821.111(73).09Twain M.

DOI: $10.4312 /$ vestnik.11.327-342

\title{
RECEPCIJA ROMANOV THE ADVENTURES OF TOM SAWYER IN ADVENTURES OF HUCKLEBERRY FINN V SLOVENIJI
}

Romana The Adventures of Tom Sawyer (1876) in Adventures of Huckleberry Finn (1884) veljata za klasični deli ameriške literature, za kateri je v izvirni kulturi vse od prvotne objave značilna živahna recepcija. ${ }^{1}$ Peter Messent navaja, da je bil za časa Twainovega življenja prvi izmed obeh romanov pozitivno sprejet predvsem zato, ker je v obdobju urbanizacije in tehnološkega napredka upodabljal preprostejši način življenja nekaj desetletij pred državljansko vojno; pozneje so nekateri sicer začeli problematizirati dejstvo, da v zgodbi suženjstvo skorajda ni omenjeno, pa tudi karakterizacija osrednjega antagonista, poimenovanega Injun Joe, je bila izpostavljena kot rasistična (2007: 13). Še veliko več črnila je bilo prelitega o romanu Adventures of Huckleberry Finn (gl. Grosman 2004b: 157-62), ki v izvirnem literarnem sistemu že od vsega začetka buri duhove in se pogosto pojavlja na seznamih prepovedane literature (Tarbox 2005: 441; Karolides, Bald in Sova 2011: 443-47). Razlogi za kontroverznost so se skozi čas sicer spreminjali: sprva so kritiki Twainu očitali predvsem neotesanost in vulgarnost, medtem ko je roman pozneje v prvi vrsti postal sporen zaradi rasističnega diskurza (zlasti uporabe rasističnega izraza 'nigger'), rasnih stereotipov in prikazovanja sužnjelastniške družbe (Devanny Jr. 2009: 356; prim. Leonard in Tenney 1992: 2). ${ }^{2}$ Kljub tovrstnim zadržkom je ta roman že desetletja v samem vrhu kanona ameriške literature - Jonathan Arac govori celo o 'hiperkanonizaciji' (1997: 7; cf. Grosman 2004b: 158).

Za razliko od nekaterih drugih uspešnih ameriških literarnih del - v letu po izidu romana Uncle Tom's Cabin (1852) sta npr. izšli kar dve slovenski priredbi - smo Slovenci na prevoda obeh zadevnih Twainovih romanov čakali več desetletij. Prvi prevod romana

1 Twain je objavil še dve nadaljevanji, tj. Tom Sawyer Abroad (1894) in Tom Sawyer, Detective (1896), ki pa ne uživata tolikšnega ugleda kot prva dva romana v tej seriji.

2 John H. Wallace npr. trdi, da gre za »najbolj grotesken primerek rasističnega šunda, ki je bil kadarkoli napisan« (1992: 16), in da ima status klasičnega literarnega dela zato, ker si mnogi Američani želijo ohraniti rasistično dediščino ZDA (ibid.: 23). 
The Adventures of Tom Sawyer je izšel leta 1921 z naslovom Mali klatež Tom Sawyer, leta 1947 je bil objavljen ponovni prevod, ki je bil naslovljen Pustolovščine Toma Sawyerja, nato pa je bilo delo leta 1960 prevedeno še tretjič, tokrat z naslovom Prigode Toma Sawyerja - slednji prevod je bil tudi sedemkrat ponatisnjen, tj. v letih 1965, 1971, 1972, 1977, 1979, 1984 in 1994. Roman Adventures of Huckleberry Finn je bil leta 1948 preveden z naslovom Pustolovščine Huckleberryja Finna, nato je leta 1962 izšel ponovni prevod, naslovljen Prigode Huckleberryja Finna, ki je bil leta 1974 ponatisnjen. ${ }^{3}$ V pričujočem prispevku bomo obravnavali status obeh Twainovih romanov v slovenskem literarnem sistemu, pri čemer bomo izhajali iz recepcijske estetike oz. teorije bralčevega odziva, ki bralce obravnava kot aktivne udeležence pri tvorbi pomena literarnih del (Pezdirc Bartol 2000: 195). Primerjali bomo odzive ob prvotnem izidu vsakega izmed prevodov in vključili tudi poznejšo recepcijo, s čimer bomo orisali t.i. zgodovinsko življenje (gl. Jauss 1970: 7-9) obeh literarnih del v slovenskem kulturnem prostoru in ugotavljali, v kolikšni meri oz. zakaj se je recepcija skozi čas spreminjala.

Izid prvega prevoda Toma Sawyerja je pospremila recenzija anonimnega avtorja, ${ }^{4} \mathrm{ki}$ je bila v skoraj identični obliki objavljena v časopisih Slovenski narod (24. 12. 1920: 3), Jutro (24. 12. 1920: 5), Slovenec (25. 12. 1920: 4) in Naprej (27. 12. 1920: 2). Zmotno je navedeno, da gre za prvi slovenski prevod katerekoli Twainove knjige (leta 1910 je namreč izšel prevod romana The Prince and the Pauper), pisatelj je opisan kot neprekosljiv pripovedovalec, glede samega romana pa je zapisano, da ga zaznamuje $»[z]$ animiva vsebina, vedno zanimanje vzbujajoče pripovedovanje, močna karakterizacija in zdravi humor, ki osvoji vsako srce«. ${ }^{5}$ V nadaljnjem zapisu v časopisu Naprej (28. 12. 1920: 3) je Twain označen kot humorist svetovnega slovesa, Tom Sawyer pa kot roman, ki lahko vsakomur nekaj ponudi: mladini je v razvedrilo, odraslim pa omogoča obujanje spominov na mladost. ${ }^{6}$ Josip Brinar v Pedagoškem zborniku prav tako objavi pozitivno recenzijo romana in še posebej pohvali način, kako je prikazan odnos med protagonistom

3 Ker sta romana v slovenščini izšla pod različnimi naslovi, bosta v nadaljevanju prispevka poimenovana Tom Sawyer in Huckleberry Finn. Recepcijo slednjega sem deloma obravnaval že v znanstvenem članku (Trupej 2015) - takrat je bila analiza narejena na podlagi bibliografije ZRC SAZU, ki zajema publikacije do leta 1970. Od objave omenjenega prispevka so na portalu Digitalna knjižnica Slovenije postale dostopne številne dotlej še ne digitalizirane publikacije, zato je namen pričujočega strokovnega prispevka celovito zajeti slovensko recepcijo obeh romanov. Pregledani korpus je zajemal približno tisoč izvodov serijskih publikacij, v katerih sta omenjena 'Tom Sawyer' in/ ali 'Huckleberry Finn'.

4 V primeru anonimnih zapisov je moška oblika uporabljena generično.

5 Slovenski narod, 24. 12. 1920: Mark Twain: Mali klatež Tom Sawyer, 3. / Jutro, 24. 12. 1920: Mark Twain: Mali klatež Tom Sawyer, 5. / Slovenec, 25. 12. 1920: Mark Twain: Mali klatež Tom Sawyer, 4. / Naprej, 27. 12. 1920: Mark Twain: Mali klatež Tom Sawyer, 2.

6 Naprej, 28. 12. 1920: Mark Twain: Mali klatež Tom Sawyer, 3. 
in njegovo izvoljenko Becky Thatcher, češ da »pisatelj pokaže, kako se tudi kočljiva vprašanja nagnjenj med dečki in deklicami dado vplesti v povest, pa to bralce — otroke prav nič ne pohujša« (1921: 120).

Naslednji omembe vreden zapis zasledimo v reviji Življenje in svet (2. 8. 1929: 128), kjer v uvodu k dvema Twainovima humoreskama navajajo, da oba romana spadata med najbolj znana dela tega pisatelja. ${ }^{7} \mathrm{~V}$ naslednjem desetletju sta Twainova najbolj slavna literarna lika omenjena v precej kritičnem kontekstu - Filip Kalan v reviji Modra ptica namreč zapiše naslednje:

Mark Twain [je] učinkoval zlasti kot romantičen, fantastičen Yankee, ki je igral nekakšnega konzula ameriške literature v 'kulturnih' deželah. Njegov klovnski humor nam danes priča samo o obupanem pesimistu Twainu in nam zbuja več usmiljenja do klovna kakor smeha zaradi šale - in da bi ne bil ustvaril genialnih paglavcev Toma in Hucka, bi nas tuljenje tega literarnega leva ne zanimalo več. (1933: 216)

V letu stoletnice Twainovega rojstva je v Slovenskem narodu (22. 1. 1935: 4) objavljen članek, v katerem je navedeno, da sta Tom Sawyer in Huckleberry Finn pisateljeva glavna literarna lika in da se Twain v ZDA po priljubljenosti lahko primerja s predsedniki, kot so George Washington, Abraham Lincoln in Woodrow Wilson. ${ }^{8}$ V reviji Radio Ljubljana (8. 12. 1935: 7) Twaina označijo za enega največjih humoristov svetovne literature, pohvalijo humor njegovih dveh osrednjih literarnih likov ter izrazijo obžalovanje, da v slovenščino ni prevedenih več pisateljevih del. ${ }^{9}$ Ko v isti reviji (11. 4. 1937: 138) napovejo izid filma The Prince and the Pauper, Twaina opišejo kot največjega ameriškega humorista in izrazijo upanje, da bo nekoč film posnet tudi po Tomu Sawyerju. ${ }^{10} \mathrm{~V}$ reviji Vzajemna svoboda sta oba romana označena kot nesmrtna in omenjeno je, da sta bila nekdaj prepovedana v marsikateri knjižnici v ZDA ter da sta nedavno postala sporna tudi v Braziliji, ker je tamkajšnja vlada v njiju odkrila komunistične tendence (N.N. 1938: 191).

Ko v Jutru (20. 2. 1939: 8) naznanijo izid filma, posnetega na podlagi Toma Sawyerja, zatrdijo, da so v mladosti vsi dečki brali znameniti istoimenski roman in uživali v Twainovem žgočem humorju. ${ }^{11}$ Naslednji mesec v istem časniku (15. 3. 1939: 3) film označijo kot izredno uspel oz. ga proglasijo za enega najlepših filmov nasploh, njegovo knjižno podlago pa označijo za klasičen roman. ${ }^{12} \mathrm{~V}$ Slovenskem narodu (15. 3. 1939: 4) trdijo, da je bil film posnet po eni najbolj priljubljenih knjig na svetu, ki ni zanimiva le

7 Življenje in svet, 2. 8. 1929: Par ameriških humoresk, 128-29.

8 Slovenski narod, 22. 1. 1935: 100 letnica rojstva Marka Twaina, 4.

9 Radio Ljubljana, 8. 12. 1935: Stoletnico [sic] Marka Twaina, 7.

10 Radio Ljubljana, 11. 4. 1937: Mark Twain v filmu, 138.

11 Jutro, 20. 2. 1939: Twainova dela v filmu, 8.

12 Jutro, 15. 3. 1939: Pustolovščine Toma Sawyerja v filmu, 3. 
za mlade, temveč tudi za odrasle bralce, saj naj bi jih zgodba spominjala na mladost, sam film pa je v članku opisan kot lep in dovršen. ${ }^{13}$ V Slovencu (16. 3. 1939: 7) zapišejo, da gre za eno najlepših filmskih umetnin ter da imata film in njegova knjižna podlaga izjemno vrednost. ${ }^{14} \mathrm{~V}$ nadaljnjem prispevku (18. 3. 1939: 7) zatrdijo, da že dolgo nobeno filmsko delo ni vsebovalo $»[\mathrm{t}]$ oliko globokih in plemenitih čustev, toliko lepote in srčne dobrote«; ta prispevek je istega dne objavljen tudi v Slovenskem narodu (18. 3. 1939: 4) in Jutru (18. 3. 1939: 4). ${ }^{15} \mathrm{~V}$ reviji Radio Ljubljana (19. 3. 1939: 4) je povzeta le zgodba filma, ${ }^{16}$ medtem ko v Mariborskem večerniku »Jutra« (15. 4. 1939: 9) film opišejo kot odličen, njegovo knjižno podlago pa označijo za 'nesmrtno'. ${ }^{17}$

\section{3}

\section{RECEPCIJA V SOCIALISTIČNEM OBDOBJU}

V letu, ko je izšel vnovičen prevod Toma Sawyerja - in še preden je izšel prevod njegovega nadaljevanja -, sta bila protagonista obeh romanov v reviji Novi svet omenjena $\mathrm{v}$ razpravi o nalogah sovjetske literarne kritike, v kateri se vpliven ruski literarni teoretik A. Fadjejev (tj. Aleksander Aleksandrovič Fadejev) opredeli tudi glede Twaina:

Marc [sic] Twain je nedvomno realist, ker resnično upodablja in kritizira pobožnjaštvo, hinavščino, pohlep in neukost ameriške družbe, resnično kaže protislovja revščine in bogastva. Obenem pa je nedvomno, da so Tom Sawyer, Tek [sic] Finn in junaki Mississippija - junaki, ki imajo dokaj romantičnih potez, in te podobe so nosilci pozitivnih naravnih idealov Marca [sic] Twaina. In ni kar tako, da ta dela živijo tako dolgo in da so najljubše berilo otrok. Vsem je znano, da je to Twainovo posebnost rodila osvobodilna borba severnih držav proti južnim. In vsem je znano, da v Združenih državah ni bilo nikoli več tako vedrih in resničnih knjig. (1947: 633-34)

Dušan Željeznov v Slovenskem poročevalcu (13. 1. 1948: 5) pod psevdonimom PJ objavi recenzijo Pustolovščin Toma Sawyerja, ${ }^{18}$ ki jo nato ob izidu Pustolovščin Huckleberryja Finna v nekoliko razširjeni različici priobči še v Mladinski reviji. Zapiše, da je Twain za izražanje svojih idej sicer izbral mladinsko povest, vendar je v njej med drugim obravnaval suženjstvo, državno oz. monarhično ureditev, purizem, konvencionalizem in

13 Slovenski narod, 15. 3. 1939: Pustolovščine Toma Sawyerja v filmu, 4.

14 Slovenec, 16. 3. 1939: Mark Twain in njegov znameniti roman »Pustolovščine Toma Swayerja«, 7.

15 Slovenec, 18. 3. 1939: Pustolovščine Toma Sawyerja v kinu Unionu, 7. / Slovenski narod, 18. 3. 1939: Pustolovščine Toma Sawyerja v kinu Unionu, 4. / Jutro, 18. 3. 1939: Pustolovščine Toma Sawyerja v kinu Unionu, 4.

16 Radio Ljubljana, 19. 3. 1939: Iz filmskega sveta, 4.

17 Mariborski večernik »Jutra«, 15. 4. 1939: Tommy Kelly, nov filmski zvezdnik, 9.

18 Slovenski poročevalec, 13. 1. 1948: Mark Twain: Tom Sawyer, 5. 
konservativizem. Recenzent citira zgornjo Fadejevo razpravo in trdi, da ameriške založbe nekaterih Twainovih del nočejo ponatisniti prav zaradi pisateljeve naprednosti, demokratičnosti in dejstva, da Združenih držav ni prikazoval v pozitivni luči. Nadalje navaja, da se predvsem v Zahodni Evropi iz angleščine praviloma prevajajo le proameriška dela vprašljive vrednosti in zato odobrava prevajanje Twainovih del v slovenščino. Željeznov se sprašuje tudi, ali romana morda nista bolj kot za mladino primerna za odrasle bralce in se zavzame za dodatek uvoda, ki bi mlajšim bralcem ustrezno pojasnil zgodovinske okoliščine dogajanja (1948: 444-45). V recenziji Toma Sawyerja v Ljudskem tedniku (29. 1. 1948: 7) avtor z inicialkami S.R. skoraj dobesedno prevzame del Fadejeve zgoraj navedene razprave - zapiše namreč, da Twain »resnično upodablja in kritizira pobožnjaštvo, hinavščino, pohlep in koristoljubje takratne ameriške družbe $\ll .{ }^{19} \mathrm{~V}$ recenziji Huckleberryja Finna, objavljeni v isti publikaciji (22. 4. 1948: 7), avtor z inicialkami R.S. podobno navaja, da Twain »biča svetohlinstvo in koristoljubje ameriške družbe 19 . stoletja ${ }^{20}{ }^{20}$ Tudi v Obzorniku anonimen recenzent obeh romanov priobči prevod zgoraj citiranega odseka Fadejeve razprave - pri čemer ne navede avtorja izvirnega zapisa (N.N. 1948: 222). Recenzent pod psevdonimom ALPA v Ljudski pravici (15. 4. 1948: 5) zapiše, da osrednjo tematiko Huckleberryja Finna predstavlja boj proti suženjstvu in navaja tudi naslednje:

[Twain] ustvarja pod plaščem nedolžnega humorja. Le redko seže po sarkazmu in le z ironijo uspešno odkriva krivičnosti, ki so se pričele pojavljati z vedno večjim napredkom kapitalizma. Strokovnjak je v popisovanju malomeščanskih prizadevanj in v smešenju verskih in posvetnih predstavnikov, ki so gospodovali v njegovi domovini.

V nadaljevanju članka recenzent zapiše, da osrednja antagonista izkoriščata »nepoučenost in zaostalost prebivalcev, [...] ljudska verska čustva, pobožnost, pristno amerikansko [sic] vnemo po patentih in žejo po senzacijah«. ALPA v romanu vidi obogatitev morale in človečnosti - trdi, da bi to mladini po vsem svetu moralo predstavljati »prvi in največji zakon družbenega reda«. ${ }^{21} \mathrm{Z}$ naslednjimi besedami pa Huckleberryja Finna ovrednoti kot 'fj' podpisan recenzent v Slovenskem poročevalcu (15. 5. 1948: 4):

Pisatelj se duhovito norčuje iz napak, kakor sta ozkosrčni puritanizem in zlagana moralnost, ki v dejanjih, posebno v ravnanju s črnimi sužnji, ne pride do izraza, iz hinavskega krščanstva nedeljskih šol, iz omejenosti in rovtarstva svojih rojakov, iz njih lahkovernosti in umazanosti ter iz bedastih in nesmiselnih preostankov srednjega veka v njihovih običajih, kakor je na primer krvna osveta. ${ }^{22}$

19 Ljudski tednik, 29. 1. 1948: Berimo nove knjige, 7.

20 Ljudski tednik, 22. 4. 1948: Berimo nove knjige. 7.

21 Ljudska pravica, 15. 4. 1948: Pustolovščine Huckleberryja Finna, 5.

22 Slovenski poročevalec, 15. 5. 1948: Mark Twain, Pustolovščine Huckleberryja Finna, 4. 
$\mathrm{V}$ istem časopisu Dušan Željeznov pri recenziji prevoda romana Citizen Tom Paine omeni, da je podobno kot Howard Fast tudi Twain s Tomom Sawyerjem in Huckleberryjem Finnom kritiziral sodobno družbo (15. 5. 1949: 3). ${ }^{23}$ Ivan Potrč v Mladini (10. 12. 1949: 5) zapiše, da Twainov humor ni bil le v »zabavo, ampak da je bil prečestokrat oster, da se je [Twain] znal kruto ponorčevati iz napak družbe, v kateri je bil prizadet človek, v prvi vrsti sta bila to pri njem brezpraven ameriški otrok ali pa tudi zamorec $\ll .{ }^{24}$ Tudi v naslednjem desetletju sta oba romana kar nekajkrat omenjena v serijskih publikacijah. Ljudska pravica (3. 11. 1951: 5) npr. objavi, kaj je Ernest Hemingway izjavil o statusu Huckleberryja Finna v Ameriškem literarnem sistemu:

Vsa moderna ameriška literatura izhaja iz ene Twainove knjige, in ta je: Huckleberry Finn. Če jo boste brali, se pa ustavite tam, ko otroci izgubijo črnega Jima. Tu je konec, ostalo je trik. Vendar je to naša najlepša knjiga in vse, kar je bilo v Ameriki napisanega, izhaja od tu: prej ni nič in pozneje nič, kar bi ji bilo enakovredno. ${ }^{25}$

V reviji Novi svet Bogomil Fatur zapiše, da se je Twain »boril zoper puritansko ozkosrčnost svoje dežele in svojega časa«, Toma Sawyerja opiše kot epsko zgodbo zgodnje ameriške dobe in trdi, da so ZDA v času, ko se je menjala Twainova in naslednja generacija književnikov, naredile »korak v žrelo modernega, neizmernega kapitalizma« (1951: 648). V reviji Naša sodobnost Fatur ponovi del zgornje izjave (1953: 748) in v nadaljevanju omeni, da je Ernest Hemingway Huckleberryja Finna pojmoval kot najboljše delo ameriške književnosti (ibid.: 753). ${ }^{26}$ V Primorskem dnevniku (13. 1. 1952: 5) in pozneje tudi v Slovenskem vestniku (27. 3. 1952: 6) je slavni odlomek o pleskanju plotu iz Toma Sawyerja naveden kot primer, kako resno se otroci lotijo dela, če so prepričani, da gre za nekaj pomembnega. ${ }^{27}$ Anonimen recenzent v časopisu Slovenski Jadran (4. 7. 1957: 5) zapiše, da je roman Tom Sawyer, Detective dobro napisan in da vsebuje socialno satiro, ${ }^{28}$ Marijan Kramberger pa v Naši Sodobnosti trdi, da je v Tomu Sawyerju »spregovorila mlada, pustolovsko ustvarjalna Amerika« (1959: 657).

$\mathrm{V}$ recenziji novega prevoda slednjega romana anonimen avtor v reviji Sodobna pota navaja, da Twain obravnava odnose med belci in temnopoltimi (N.N. 1960: 363). V Delu

23 Slovenski poročevalec, 15. 5. 1949: Fastov Tom Paine, 3.

24 Mladina, 10. 12. 1949: Mark Twain pisatelj sonca in smeha, 5.

25 Ljudska pravica, 3. 11. 1951: Pogovor o ameriški književnosti, 5. V izvirnem citatu (gl. Hemingway [1935] 2002: 23) je uporabljen rasističen izraz 'nigger', v prevodu pa nevtralen izraz 'črn' - tovrstne strategije so bile pri prevajanju rasističnih izrazov v slovenščino pogosto uporabljene (gl. Trupej 2014).

26 Tudi Rapa Šuklje pozneje v isti reviji zapiše, da je Twainov opus, predvsem Huckleberry Finn, vplival na Ernesta Hemingwaya (1961: 963-64).

27 Primorski dnevnik, 13. 1. 1952: Delo in dobro berilo, 5. / Slovenski vestnik, 27. 3. 1952: Delo in dobro berilo uspešno vzgojno sredstvo, 6.

28 Slovenski Jadran, 4. 7. 1957: Tom - mali detektiv, 5. 
(1. 4. 1960: 6) Twaina označijo kot družbenega filozofa, ki ga t.i. izgubljena generacija v 20. letih prejšnjega stoletja sicer ni cenila v tolikšni meri kot predhodne generacije, vendar se je to pozneje spremenilo predvsem zaradi Huckleberryja Finna, ki so ga bralci začeli uvrščati v sam vrh literarnega kanona. ${ }^{29}$ Prav tako v Delu (4. 3. 1961: 6) je recenzent, podpisan kot 'Jaš', zadržan do filma, posnetega po Tomu Sawyerju, saj naj bi se v njem izgubila ostra družbena satira. ${ }^{30} \mathrm{Ob}$ izidu Prigod Huckleberryja Finna anonimen avtor v reviji Knjiga zapiše, da skozi protagonistove oči »gledamo temne strani ameriškega civilizatorskega gibanja« (N.N. 1962: 202), medtem ko Jože Snoj v reviji Naši razgledi (22. 12. 1962: 487) navaja, da je ta roman »sočna deška avantura po Mississippiju v čolnu nezadržne civilizacije in z vetrom zdravega občutenja življenja v boku«. ${ }^{31}$ V Slovenskem Jadranu (1. 1. 1963: 16) je navedeno, da je Huckleberry Finn eno izmed del, ki so Twainu prinesla nesmrtnost, omenjeno pa je tudi Hemingwayevo mnenje o tem romanu. ${ }^{32}$ France Magajna v Primorskem dnevniku (19. 11. 1963: 3) zapiše, da je Twain največji ameriški humorist, ki je pri nas najbolj znan prav zaradi Toma Sawyerja in Huckleberryja Finna ter njunih dogodivščin. ${ }^{33} \mathrm{~V}$ Delu (15. 9. 1964: 9) objavljen članek o mestu Hannibal, kjer je Twain preživel mladost, obelodani, v kolikšni meri je to mesto navdihnilo dogajanje Toma Sawyerja. ${ }^{34}$ Olga Ratej v istem časniku (20. 2. 1966: 6) zapiše, da po slednjem romanu posneta serija ni tako uspela kot film, posnet po Huckleberryju Finnu. ${ }^{35}$ Stanka Godnič prav tako v Delu (28. 4. 1967: 5) gledališko predstavo z naslovom 'Velika pustolovščina Toma Sawyerja' kritizira zato, ker naj bi bila prirejena tako, da je »na odru jasneje izstopila protirasistična zavzetost, ki dobiva ponekod že poteze poenostavljene, literarne edukativnosti «. ${ }^{36} \mathrm{~V}$ uvodu k odlomku iz Twainove avtobiografije, objavljene v Dolenjskem listu (8. 5. 1969: 17), je Huckleberry Finn naveden kot eno njegovih najpomembnejših del. ${ }^{37}$

V zadnjih dveh desetletjih socialističnega obdobja so omembe obeh romanov dokaj redke in precej manj poglobljene kot v prejšnjih desetletjih. V časniku Glas (23. 9. 1977: 10) npr. Huckleberryja Finna in Toma Sawyerja označijo kot klasična lika mladinske literature, ${ }^{38}$ v Primorskem dnevniku $(1.6 .1980,7)$ pa zasledimo zapis, da so učenci lokalne osnovne šole uprizorili predstavo o slednjem liku. ${ }^{39} \mathrm{~V}$ Delu $(12.8 .1981,6)$ poro-

29 Delo, 1. 4. 1960: Nocoj Mark Twain, 6.

30 Delo, 4. 3. 1961: Pustolovščine Toma Sawyerja, 6.

31 Naši razgledi, 22. 12. 1962: O novih knjigah. 487.

32 Slovenski Jadran, 1. 1. 1963: Mark Twain: Prigode Huckleberryja Finna, 16.

33 Primorski dnevnik, 19. 11. 1963: Burkež Mark Twain, 3.

34 Delo, 15. 9. 1964: Hannibal - mesto Toma Sawyerja, 9.

35 Delo, 20. 2. 1966: Naš preTVornik, 6.

36 Delo, 28. 4. 1967: Velika pustolovščina Toma Sawyerja, 5.

37 Dolenjski list, 8. 5. 1969: Avtobiografija, 17.

38 Glas, 23. 9. 1977: Ta teden na TV, 10.

39 Primorski dnevnik, 1. 6. 1980: Naše šolske prireditve, 7. 
čajo, da se pogosto pojavljajo zahteve po cenzuri Huckleberryja Finna širom ZDA, ${ }^{40} \mathrm{~V}$ Slovenskem vestniku (23. 12. 1987: 9) pa film, posnet po Toти Sawyerju, opišejo kot zelo napet in zanimiv. ${ }^{41}$ Izjema je poglobljena znanstvena razprava Mete Grosman (1987) o Huckleberryju Finnu v reviji Acta neophilologica, kjer avtorica ugotavlja, da protagonist resničnost dojema na drugačen način kot njegovi vrstniki oz. da ima pluralističen pogled na svet predvsem zato, ker je odraščal brez stalne prisotnosti staršev in je veliko časa preživel v družbi temnopoltih.

\section{$4 \quad$ RECEPCIJA V POST-SOCIALISTIČNEM OBDOBJU}

Tom Sawyer je sicer tudi po osamosvojitvi ostal na seznamu domačega branja v osnovnih šolah (Mazi-Leskovar 1996: 25), vendar ta roman in njegovo nadaljevanje že več kot pol stoletja nista bila ponovno prevedena, slednji pa v obdobju samostojne Sloveniji tudi ni bil nikdar ponatisnjen, zato ne preseneča, da je poglobljenih publicističnih zapisov o obeh romanih $\mathrm{v}$ tem obdobju nekoliko manj kot $\mathrm{v}$ desetletjih, ko sta bili deli prevedeni.

V Delu (23. 7. 1992: 11) v kratkem članku poročajo, da je Shelley Fisher Fishkin napisala monografijo z naslovom Was Huck Black?, v kateri razpravlja o možnosti, da je Twainu kot navdih za protagonista v Huckleberryju Finnu služil nek temnopolti deček. V članku je omenjeno tudi, da ta roman, ki je preusmeril tok ameriške književnosti, mnogi obsojajo zaradi uporabe izraza črnuh. ${ }^{42} \mathrm{~V}$ istem časniku ob obletnici Twainovega rojstva (30. 11. 1996: 16) Toma Sawyerja in Huckleberryja Finna navedejo kot njegova najslavnejša literarna lika, ${ }^{43} \mathrm{v}$ poznejšem članku (14. 7. 1998: 17) pa zatrdijo, da je s Huckleberryjem Finnom Twain izrazil odpor do sužnjelastniškega sistema. ${ }^{44}$ Dejan Kovač v Dnevniku (9. 8. 2004: 5) navaja, da so bralci ob dogodivščinah obeh literarnih likov spoznavali rasne napetosti in siromaštvo ob Mississippiju..$^{45}$ Tina Bilban v reviji Ampak zapiše, da je za Flisarjev roman $\check{C} a j$ s kraljico značilen neustavljiv ritem življenja, primerljiv s tistim v Huckleberryju Finnu (2005: 87).

Leta 2009 je Slovensko ljudsko gledališče Celje uprizorilo predstavo z naslovom 'Tom Sawyer in vražji posli', ki je nastala po Twainovi literarni predlogi. Ob tej priložnosti je na portalu Sigledal (2. 10. 2009) Twain označen kot oče ameriškega romana in največji humorist 19. stoletja, ki jih v svojih delih prikazoval tudi temne plati širjenja ameriške civilizacije na zahod. Opisano je ozadje nastajanja Toma Sawyerja in tudi Huckleberryja Finna, ki velja za njegovo najboljše delo, a je obenem kontroverzno zaradi pogoste rabe izraza 'nigger'. Omenjeno je tudi, da je bil Twain kritičen do organizirane

40 Delo, 12. 8. 1981: Cenzurirani književniki, 6.

41 Slovenski vestnik, 23. 12. 1987: Tom Sawyer, 9.

42 Delo, 23. 7. 1992: Je bil Huck Finn črnec?, 11.

43 Delo, 30. 11. 1996: 30. november, 16.

44 Delo, 14. 7. 1998: Velike knjige: Pustolovščine Huckleberry [sic] Finna, 2. del, 17.

45 Dnevnik, 9. 8. 2004: Predsodki prepovedane ljubezni, 5. 
religije in zagovornik pravic žensk ter temnopoltih, vendar ni imel pozitivnega mnenja o ameriških staroselcih - obstaja teorija, da je bil prav zato osrednji antagonist v Tomu Sawyerju Indijanec Joe. ${ }^{46}$ Premiera te predstave je bila med drugim napovedana tudi na spletnem portalu časopisa Dnevnik (2. 10. 2009). ${ }^{47}$

Ko je Huckleberry Finn v Sloveniji izšel v skrajšani različici, namenjeni predvsem otrokom od osmega do trinajstega leta, so na spletnem portalu Regional (5. 1. 2013) to priredbo na kratko predstavili. ${ }^{48}$ Alenka Bole Vrabec na spletnem portalu časopisa Gorenjski glas navaja, da je bil Twain kritik ameriške družbe in rasizma ter da je v svojih delih bičal pohlep in sprenevedanje višjih družbenih slojev. Omeni, kaj je o Huckleberryju Finnu izjavil Hemingway, in trdi, da se protagonist tega romana vse do danes ni nič postaral, Twain sam pa prav tako ne $(25.11 .2018) .{ }^{49}$

Oba romana sta pustila vtis tudi pri nekaterih vidnih slovenskih intelektualcih. Jezikoslovec Tomo Korošec je npr. izjavil, da je v otroštvu bral o dogodivščinah Toma Sawyerja in Huckleberryja Finna in jih podoživljal v Laškem ob reki Savinji (2010: 31; gl. tudi Košak 2014: 7), romana pa sta se v spomin vtisnila tudi predsedniku Slovenske akademije znanosti in umetnosti Tadeju Bajdu (11. 4. 2015) ${ }^{50}$ in pisatelju Slavku Preglu (27. 3. 2018: 15)..$^{51}$

$\mathrm{V}$ posameznih zapisih je nekoliko podrobneje obravnavana tudi problematika rasizma v Huckleberryju Finnu. Lejla Švabič je na spletnem portalu MMC (5. 1. 2011) npr. objavila prispevek o tem, da bo v novi ameriški izdaji, ki jo je priredil Alan Gribben, izraz 'nigger' cenzuriran. ${ }^{52}$ Še nekoliko daljši prispevek s podobno vsebino je na spletnem portalu časopisa Delo objavila Jožica Grgič, ki posege v izvirni roman primerja s težnjo po politični korektnosti v Sloveniji: »Kakor se je v tem duhu pri nas Cigan spremenil v Roma in Žid v Juda, bo Twainov črnuh (nigger) postal suženj (slave), injun, neformalni ali narečni izraz za Indijanca, pa bo zamenjan z Indijancem.« Grgičeva pojasni zgodovinsko ozadje nastanka romana in zmotno trdi, da izraz 'nigger' za časa Twainovega življenja še ni imel negativne konotacije. Povzame kritične poglede na Gribbenovo početje:

Zaradi posega v avtorstvo so se nanj in na založbo zgrnile številne kritike, češ da posegi v Twainov način pripovedovanja pomenijo tudi spremembe v sporočilu, ki ga prinaša, in da je tako pisal, ker nas je hotel prisiliti k razmišljanju in

46 Sigledal, 2. 10. 2009: Mark Twain in Tom Sawyer. http://veza.sigledal.org/prispevki/mark-twain-in-tomsawyer (Dostop 26. 3. 2019).

47 Dnevnik, 2. 10. 2009: Navihano odraščanje. https://www.dnevnik.si/1042303834 (Dostop 26. 3. 2019).

48 Regional, 5. 1. 2013: Na hitro prelistano: novosti na domačem knjižnem trgu. https://www.regionalobala.si/ novica/na-hitro-prelistano-novosti-na-domacem-knjiznem-trgu (Dostop 27. 3. 2019).

49 Gorenjski glas, 25. 11. 2018: Po Misisipiju in Evropi. http://www.gorenjskiglas.si/article/20181125 /C/181129885/1002/po-misisipiju-in-evropi/\&template=komentar (Dostop 27. 3. 2019).

50 Rastoča knjiga, 11.4. 2015: Misli in govori. http://rastocaknjiga.si/?p=tadej-bajd.html (Dostop 26. 3. 2019).

51 Delo, 27. 3. 2018: Slavko, če boš priden, iz tebe nekoč nekaj bo, 15.

52 MMC, 5. 1. 2011: Huckleberry Finn v novi izdaji z «olepšanim» jezikom. https:/www.rtvslo.si/kultura/knjige/ huckleberry-finn-v-novi-izdaji-z-olepsanim-jezikom/247895 (Dostop 27. 3. 2019). 
zbosti z ostrino svojega peresa. V času, ko je Twain roman pisal, so uporabljali takšne izraze, in če se jih vzame iz ust likov, se s tem spremeni njihov karakter, kar spreminja prikaz tedanjega časa in razmer. Zelo pomembno sporočilo knjige je, da je bil Huckleberry Finn sprva rasist, a je spremenil svoje nazore, ko je zapustil rasistično družbo. $Z$ novimi izrazi se ta preobrazba zabriše in potvori sporočilo zgodbe..$^{53}$

Ko Jožica Grgič pozneje v Delu (20. 12. 2016: 16) poroča, da so v nekaterih šolah v ameriški zvezni državi Virginia na zahtevo staršev iz učnega programa umaknili romana Adventures of Huckleberry Finn in To Kill a Mockingbird, navaja da je bil problematičen rasističen jezik, predvsem pogosta uporaba izraza 'nigger', ki pa je v oklepaju preveden $\mathrm{v}$ 'črnec' in ne npr. 'črnuh', s čimer je rasistični naboj izraza v tem članku izničen. $\mathrm{O}$ problematiki rasizma v Huckleberryju Finnu je v intervjuju, objavljenem v Sobotni prilogi (30. 8. 2014: 4), spregovoril tudi Robert B. Silvers, urednik prestižne revije The New York Review of Books:

Prvič v zgodovini ameriške književnosti smo lahko prebrali tako naravno izražanje mladeniča ... Čeprav so v zadnjih letih uredniki nekaterih založb nepotrebno posegli v Twainov izvirnik zaradi uporabe določenih besed za sužnje in temnopolte. A slednji ne razumejo, za kaj gre: Twainove knjige niso le literarni dokumenti, ampak tudi zgodovinski, in prav beseda črnuh zaobjema nasilnost suženjstva. Twain popiše, da je Huckleberry Finn na začetku rasist v rasistični družbi, a to družbo zapusti in spremeni svoje nazore. Namen literature ni v tem, da nas zavija $\mathrm{v}$ vato - in realist Twain je to odlično udejanjil s svojimi deli -, temveč $\mathrm{v}$ intenci, da nas izpostavi različnim idejam in obdobjem, ki ne bodo vedno prijazna in nenevarna. ${ }^{54}$

Kar zadeva slovensko strokovno oz. znanstveno literaturo, sta bila oba romana v zadnjih desetletjih obravnavana predvsem v reviji Otrok in knjiga, ki je posvečena otroški in mladinski književnosti. Darja Lavrenčič Vrabec v tej publikaciji npr. navaja, da je Twain $\mathrm{v}$ obeh romanih odrasle občasno prikazoval v negativni luči in da so se njegovi mladi protagonisti včasih tudi 'grdo' obnašali, zato sta bili knjigi v ameriški javnosti sporni in si ju mladi v nekaterih knjižnicah sploh niso smeli sposoditi (2001: 43; 2002: 49). Nike K. Pokorn obravnava ideološko ozadje prevajanja Toma Sawyerja: navaja, da je bil prvi prevod poln arhaizmov in je bil po vojni ponovno preveden, vendar ta prevod nato ni bil nikdar ponatisnjen, ker je bila prevajalka Milena Mohorič leta 1949 obsojena kot informbirojevka in povsem izbrisana iz javnega življenja, medtem ko je

53 Delo, 7. 1. 2011: Cenzurirane Prigode Huckleberryja Finna. https://www.delo.si/kultura/cenzurirane-prigodehuckleberryja-finna.html (Dostop 27. 3. 2019).

54 Sobotna priloga, 30. 8. 2014: Imamo svoje mnenje o vsem. Lahko. 4. 
Gradišnikov prevod iz leta 1960 doživel številne ponatise (2012: 25). Irena Avsenik Nabergoj oba romana omenja $\mathrm{v}$ članku o osirotelih otrocih in navaja, da Twain v teh dveh delih obravnava družbeno izolacijo otrok in prizadevanje za osvoboditev od družbenega konformizma (2017: 99).

Nekoliko bolj podrobno se je z obema romanoma ukvarjala Darja Mazi-Leskovar, ki Toma Sawyerja prišteva med najbolj zabavne knjige ameriške mladinske književnosti, o njegovem nadaljevanju pa zapiše, da »ne pripoveduje le o nenavadnem mladostniku, ki presoja svet s svojimi očmi in s svojim srcem, marveč tudi o ameriški družbi, ki se je borila s suženjstvom, s krvno osveto in s praznoverjem« (1997a: 45). V nadaljnjem prispevku v reviji Otrok in knjiga avtorica navaja, da Twain s Tomom Sawyerjem bralcev ni le zabaval, temveč tudi vzgajal, romana Tom Sawyer Abroad in Tom Sawyer, Detective označi kot deli, v katerih se »kalijo poštenje, družbena odgovornost in ljubezen do bližnjega«, glede Twainovih namenov s Huckleberryjem Finnom pa zapiše naslednje:

Izpostavil je predvsem vprašanje enakopravnosti pred zakonom. S tem je nedvomno pokazal na neznosen položaj, v katerem se je znašel velik del ameriškega prebivalstva - ne le črncev, ki so bili izpostavljeni kot žrtve, temveč tudi tistih belcev, ki niso mogli sprejemati nečloveške zakonodaje. In teh v Twainovih mladinskih delih ni malo! Njihov najodličnejši predstavnik, Huckleberry Finn, se po večdnevnem razglabljanju in spraševanju vesti zavestno odloči, da raje tudi sam krši zakon (da je raje pogubljen), kot da ne bi pomagal pobeglemu sužnju, ki, na fantovo veliko začudenje, čuti in doživlja svet podobno kot on sam. Iz tega velikega odkritja, da je namreč črni človek v bistvu ravno tak kot beli, izhaja Huckovo spoznanje, da so Jimove želje po svobodi vsaj toliko legitimne, kot njegova potreba, da je sam svoj gospodar. (Mazi-Leskovar 1997b: 118)

V novejšem prispevku Mazi-Leskovarjeva oba romana prišteva v sam vrh mladinske književnosti in navaja, da ju je mladina sprejela z navdušenjem; prvi roman naj bi se v večji meri uveljavil med mlajšimi bralci, slednji pa kot zahtevnejše delo med nekoliko starejšimi mladostniki (2010: 25). Glede recepcije slednjega dela izpostavi, da so ga kritiki večinoma sprejeli z odobravanjem, vendar je bilo zaradi 'prostaškega' jezika deležno tudi kritik. Nadalje navaja, da so v prvi polovici 20. stoletja nekateri kritiki začeli kritizirati 'umetniškost' zaključnih poglavij, v drugi polovici stoletja pa je roman postal sporen zaradi jezika, ki je bil žaljiv do Afroameričanov, in ker naj bi Jimova karakterizacija utrjevala negativne rasne stereotipe (ibid.: 26). Glede vsebine romana pa Mazi-Leskovarjeva zapiše naslednje:

Huck, glavni junak dela, ki je nastalo kot nadaljevanje Toma Sawyerja, se namreč sooča s samim seboj, z iskanjem svoje osebne in družbene identitete. Je v precepu med poslušnostjo svojim notranjim občutjem in svojim védenjem o 
tem, kaj je družbeno sprejemljivo. Na sebi lasten način se odziva na družbene razmere, za katere čuti, da niso pravične. Zmore se prepustiti celi paleti čustev, tudi takim, ki so sad zavračanja posameznikov, skupin in družbe, v kateri naj bi živel. S tem ko razmišlja o vprašanjih svojega časa in prostora, se dotika občečloveških izzivov, s katerimi se soočajo razmišljujoči mladostniki vseh časov: vprašanj o svobodi, človeškem dostojanstvu, pravici do kritičnega mnenja in pomenu predpisov in zakonov. (ibid. 25-26)

Meta Grosman se v prispevku, objavljenem reviji Otrok in knjiga (1999a; prim. Grosman 1999b), ki je nadgradnja članka iz leta 1987, ukvarja z vprašanjem, na kakšen način je pomanjkanje primarne socializacije vplivalo na to, kako Huckleberry Finn razume svet okoli sebe, pa tudi z vprašanjem, kako bralcem v medkulturnem položaju, ki imajo drugačno obzorje pričakovanja od bralcev v izvirni kulturi, odstreti globlje pomene dogajanja v romanu. Grosmanova v nadaljnjem prispevku v tej reviji navaja, da Huckleberry Finn v izvirni kulturi ne velja za mladinsko delo, temveč za klasično besedilo, ki je primerno tudi za mlade bralce. Poleg tega trdi, da je Gradišnikova spremna beseda bolj primerna za odrasle bralce in ne za bralce med dvanajstim in štirinajstim letom, ki naj bi bili primarna ciljna publika za slovenski prevod (2004a: 11-12). Grosmanova je o tem romanu pisala tudi $\mathrm{v}$ znanstvenih monografijah $(1995,2004 \mathrm{~b})$, tako da se je $\mathrm{z}$ njim verjetno ukvarjala največ od vseh slovenskih literarnih teoretikov.

\section{5}

\section{SKLEP}

Pregled recepcije je pokazal, da sta imeli obe deli v slovenskem prostoru precej pestro 'zgodovinsko življenje'. V obdobju med obema vojnama je bil nekaj pozornosti v publicističnem tisku deležen predvsem roman The Adventures of Tom Sawyer. Izid prevoda iz leta 1920 so pospremile najmanj tri recenzije, od katerih je bila ena objavljena $\mathrm{v}$ štirih časnikih. V naslednjem desetletju in pol sta bila protagonista obeh romanov sporadično omenjena $\mathrm{v}$ tisku, pri čemer ni opaziti razlik med zapisi v konservativnih in liberalnih publikacijah, $v$ drugi polovici tridesetih let pa se je poročalo predvsem o filmu, ki je bil posnet po starejšem izmed obeh romanov. $\mathrm{V}$ vseh pregledanih zapisih iz tega obdobja sta romana obravnavana kot mladinska literatura, ideoloških vplivov pa v člankih skorajda ni opaziti.

Slednje se je po vzpostavitvi socialističnega sistema v Jugoslaviji občutno spremenilo. V prvih povojnih letih sta izšla prevoda obeh romanov in naletela na izjemno živahen odziv; v številnih recenzijah zasledimo obsodbe rasizma, religije, kapitalizma in različnih razsežnosti ameriške družbe. Po tem, ko je bila Jugoslavija leta 1948 izključena iz Informbiroja in se je precej bolj približala zahodnemu bloku, so omembe obeh romanov postale občutno manj pogoste in kritične do Združenih držav. Po Stalinovi smrti in 
normalizaciji odnosov s Sovjetsko zvezo sredi petdesetih let in predvsem po ustanovitvi Gibanja neuvrščenih v člankih zopet zasledimo večjo mero kritičnosti do ZDA, vendar nikdar več v tolikšni meri kot v prvih povojnih letih. V zadnjih dveh desetletjih socialističnega sistema sta obe deli v publicističnem tisku omenjeni precej redkeje kot prej, k čemur je zagotovo botrovalo tudi dejstvo, da vse od začetka šestdesetih let nista bila ponovno prevedeni.

V obdobju samostojne Slovenije sta bila romana deležna določene mere pozornosti tako v publicističnem kot v strokovnem tisku. Čeprav je bil predvsem roman Adventures Huckleberry Finn predmet nekaterih poglobljenih razprav, je iz recepcije razvidno, da ima v slovenskem kulturnem prostoru primarno status mladinskega dela in ne spada v vrh literarnega kanona (prim. Grosman 2004b: 144). Verjetno so predvsem zaradi različnih zgodovinskih izkušenj z rasizmom do temnopoltih (prim. Grosman 1995: 34; 2004b: 145) določeni vidiki tega romana, ki so v izvirni kulturi že desetletja problematizirani, v slovenskem kulturnem prostoru precej manj pogosto izpostavljeni kot sporni. Deloma je k temu verjetno botrovalo tudi dejstvo, da je bil v prevodih obeh romanov rasistični diskurz nekoliko omiljen (gl. Trupej 2014: 97-99).

\section{BIBLIOGRAFIJA}

AVSENIK NABERGOJ, Irena (2017) Children Without Childhood: The Emotionality of

Orphaned Children and Images of Their Rescuers in Selected Works of English and Canadian Literature. Acta Neophilologica 50 (1/2), 95-135.

ARAC, Jonathan (1997) Huckleberry Finn as Idol and Target: The Functions of Criticism in Our Time. Wisconsin: The University of Wisconsin Press.

BILBAN, Tina (2005) Evald Flisar: Čaj s kraljico. Ampak 6 (6), 87.

BRINAR, Josip (1921) Novejše slovstvo za mladino. Pedagoški zbornik 19, 114-132.

DEVANNY Jr., John Francis (2009) The Moral Geography of Huckleberry Finn. Mark

Twain in Mary R. Reichardt (ur.), Adventures of Huckleberry Finn. San Francisco: Ignatius Press, 353-366.

FATUR, Bogomil (1951) Ameriška literatura in Sinclair Lewis. Novi svet 6 (7/8), 638-662.

FATUR, Bogomil (1953) Ernest Hemingway ali sodobna ameriška zavest. Naša sodobnost $1(7 / 8), 747-759$.

GROSMAN, Meta (1987) The Pluralistic World of Huckleberry Finn. Acta neophilologica 20, 53-62.

GROSMAN, Meta (1995) Multicultural Perspectives on Huckleberry Finn: Including a Look at the Lack of Primary Socialization in Huck's Development. Meta Grosman (ur.), American Literature for Non-American Readers: Cross-Cultural Perspectives on American Literature. Frankfurt na Majni: P. Lang, 33-47. 
GROSMAN, Meta (1999a) Huckleberry Finn v medkulturni perspektivi. Darka Tancer-Kajnih (ur.), Otrok in knjiga: Prispevki s simpozija Perspektive v mladinski književnosti, 75-87.

GROSMAN, Meta (1999b) Reading Huckleberry Finn Across Cultures. Language and Literature 24, 65-78.

GROSMAN, Meta (2004a) Kdo je naslovnik kritike mladinske književnosti. Otrok in knjiga 60, 5-15.

GROSMAN, Meta (2004b) Književnost v medkulturnem položaju. Ljubljana: Znanstveni inštitut Filozofske fakultete.

HEMINGWAY, Ernest (2002) Green Hills of Africa. New York: Simon \& Schuster.

JAUSS, Hans Robert (1970) Literary History as a Challenge to Literary Theory. Prevod: Elizabeth Benzinger. New Literary History 2 (1), 7-37.

KALAN, Filip (1933) Amerika in Lewisov Dr. Arrowsmith. Modra ptica 4 (7), 215-221.

KAROLIDES, Nicholas J./Margaret BALD/Dawn B. SOVA (2011) 120 Banned Books:

Censorship Histories of World Literature, Second Edition. New York: Checkmark Books.

KOŠAK, Nika (2014) Častni občan dr. Tomo Korošec. Laški bilten 45, 7.

KOROŠEC, Tomo (2010) OŠ Primoža Trubarja Laško skozi čas: 2. del. Laški bilten 16, 31.

KRAMBERGER, Marijan (1959) Štiri mladinske knjige. Naša sodobnost 7 (7), 656-658. LAVRENČIČ VRABEC, Darja (2001) Bolečina odraščanja: droge, seks in ...*. Otrok in knjiga 52, 40-51.

LAVRENČIČ VRABEC, Darja (2002) Cenzura in druge oblike prepovedovanja knjig ter mladinska književnost. Otrok in knjiga 53, 38-54.

LEONARD, James S./Thomas. A. TENNEY (1992) Introduction. J. S. Leonard, T. A. Tenney in T. M. Davis (ur.), Satire or Evasion? Black Perspectives on Huckleberry Finn. Durham/London: Duke University Press, 1-11.

MAZI-LESKOVAR, Darja (1996) Ameriška mladinska proza. Otrok in knjiga 42, 25-30. MAZI-LESKOVAR, Darja (1997a) Ameriška mladinska proza od začetkov do konca 19. stoletja. Otrok in knjiga 43, 41-49.

MAZI-LESKOVAR, Darja (1997b) Moralnovzgojna funkcija v ameriški mladinski prozi 19. stoletja. Otrok in knjiga 44, 113-121.

MAZI-LESKOVAR, Darja (2010) Varuh v rži in ameriški mladinski roman. Otrok in knjiga 77, 20-33.

MESSENT, Peter (2007) The Cambridge Introduction to Mark Twain. Cambridge: Cambridge University Press.

N. N. (1938) Iz zgodovine cenzure. Vzajemna svoboda 2 (11), 191-192.

N. N. (1948) Pustolovščine Huckleberryja Finna. Obzornik 3 (5), 222.

N. N. (1960) Prigode Toma Sawyerja. Sodobna pota 5 (8), 363.

N. N. (1962) Prigode Huckleberry [sic] Finna. Knjiga 10 (11/12), 202. 
PEZDIRC BARTOL, Mateja (2000) Vloga bralca v poglavitnih literarnoteoretičnih smereh 20. stoletja [I. del]. Jezik in slovstvo 45 (5), 195-206.

POKORN, Nike K. (2012) Dialektičnomaterialistična indoktrinacija mladine prek prevodov. Otrok in knjiga 84, 22-31.

ŠUKLJE, Rapa (1961) Ernest Hemingway. Naša sodobnost 9 (11), 961-968.

TARBOX, Gwen Athene (2005) American Children's Narrative as Social Criticism, 1865-1914. R. P. Lamb in G. R. Thompson (ur.), A Companion to American Fiction 1865-1914. Oxford: Blackwell Publishing, 428-448.

TRUPEJ, Janko (2014) Prevajanje rasističnega diskurza o temnopoltih v slovenščino. Primerjalna književnost 37 (3), 89-109.

TRUPEJ, Janko (2015) Recepcija štirih ameriških romanov in njihovih slovenskih prevodov v luči ideologije rasizma. Primerjalna književnost 38 (2), 213-235.

WALLACE, John H. (1992) The Case Against Huck Finn. J. S. Leonard, T. A. Tenney in T. M. Davis (ur.), Satire or Evasion? Black Perspectives on Huckleberry Finn. Durham/London: Duke University Press, 16-24.

ŽELJEZNOV, Dušan (1948) Ob dveh Mark Twainovih knjigah v slovenščini. Mladinska revija 3 (10), 444-445.

\section{POVZETEK}

Prispevek obravnava slovensko recepcijo romanov The Adventures of Tom Sawyer in Adventures of Huckleberry Finn - dveh klasičnih literarnih del, ki sta bili v slovenščino prevedeni večkrat. Analiza, ki je utemeljena na teoriji bralčevega odziva, je zajemala približno tisoč številk slovenskih serijskih publikacij (vključno z znanstvenim tiskom) in je pokazala, v kolikšni meri se slovenska recepcija razlikuje od tiste $\mathrm{v}$ izvirni kulturi. Ker je analiza razdeljena na obdobje med obema svetovnima vojnama, socialistično obdobje in obdobje po slovenski osamosvojitvi, osvetli, kako se je recepcija skozi čas spreminjala. Ob upoštevanju socio-političnih okoliščin v posamezni dobi je mogoče sklepati tudi, zakaj se je način, kako se je pisalo o obeh literarnih delih, včasih precej spremenil celo v nekaj letih. Med obema vojnama pri recepciji ni opaziti izrazitih ideoloških vplivov, med socialističnim obdobjem pa $\mathrm{v}$ recenzijah pogosto zasledimo obsodbe rasizma, kapitalističnega sistema, organizirane religije in drugih razsežnosti ameriške družbe. To je najbolj značilno za recenzije, ki so bile objavljene v prvih nekaj letih po 2. svetovni vojni; ko so se odnosi med ZDA in Jugoslavijo občutno izboljšali, se to odraža tudi v recepciji zadevnih romanov. Po slovenski osamosvojitvi sta romana zopet obravnavana predvsem kot mladinska književnost in večina zapisov o njiju nima izrazitega ideološkega naboja.

Ključne besede: recepcija, ameriška književnost, Mark Twain, Tom Sawyer, Huckleberry Finn 


\section{ABSTRACT \\ The reception of the novels The Adventures of Tom Sawyer and Adventures of Huckleberry Finn in Slovenia}

The article addresses the Slovenian reception of the novels The Adventures of Tom Sawyer and Adventures of Huckleberry Finn - two classic literary works that have been translated into Slovenian more than once. The analysis, based on reader response theory, encompassed approximately one thousand issues of Slovenian serial publications (including academic print), and shed light on the extent to which the Slovenian reception differed from that in the original culture. Since the analysis is divided into the period between the two world wars, the socialist period and the period after Slovenia gained independence, it illuminates how the reception changed over time. Considering the socio-political circumstances during a particular period makes it possible to reach conclusions about why writing about both literary works sometimes changed considerably even within a few years. In the interwar period, no clear ideological influences are evident, while during the socialist period there are frequent condemnations of racism, capitalism, organized religion and other aspects of American society. This is most characteristic of the reviews that were published in the first few years after World War II; then, after relations between the United States and Yugoslavia improved significantly, this was reflected in the reception of the novels in question. In the period after Slovenia declared independence, both novels were again primarily considered to be juvenile literature, and most articles about them do not have an ideological agenda.

Keywords: reception, American literature, Mark Twain, Tom Sawyer, Huckleberry Finn 